\title{
A Gini decomposition analysis of inequality in the Czech and Slovak Republics during the transition ${ }^{1}$
}

\section{Thesia I. Garner* and Katherine Terrel1**}

\author{
*Bureau of Labor Statistics \\ US Department of Labor \\ Washington D.C. \\ USA \\ Tel: + (1) 2026066579 Ext.596 \\ Fax: + (1) 2026066583 \\ E-mail: Garner_t@BLS.gov
}

\author{
**University of Michigan Business School \\ and William Davidson Institute \\ Ann Arbor \\ Michigan 48109 \\ Tel: + (1) 7346475844 \\ Fax: + (1) 7349368715 \\ E-mail: terrell@umich.edu
}

\begin{abstract}
Disposable income inequality, as measured by the Gini coefficient and using the Family Budget Survey data, increased very little, and by a similar amount, from 1989 to 1993 in the Czech Republic and Slovakia. This surprising result is examined with an analysis of changes in the channels of redistribution and a Gini decomposition. We find that the sizeable increase in overall inequality due to changes in the wage earnings component is mitigated by changes in the tax and transfer components in both republics. As for the relative effects of government policies, changes in the transfer component contributed more than changes in the tax component to lowering the growth of inequality in the Czech Republic, while the reverse was true for Slovakia.
\end{abstract}

JEL classification: D10, D31, H24, P30, P52.

Keywords: household income, inequality, taxes, transfers, transition.

\section{Introduction}

Under the Soviet system, the Central and East European (CEE) countries maintained the most equal distributions of income in the world. Even the Soviet Union, while less remarkable in this respect, achieved a relatively egalitarian income distribution (Atkinson and Micklewright, 1992). Greater income inequality was therefore an expected outcome of a transition to a market economy.

With five to seven years of observations on the transition, two models of the process have emerged within the former Soviet bloc. Russia and other newly independent states (NIS) 
suffered a profound and continuous decline in GDP as the centrally planned system disintegrated, government tax revenue plummeted and a weak social safety net was put in place. On the other hand, the $\mathrm{CEE}$ economies experienced only a brief period of economic decline, followed by growth within a newly introduced market system. Moreover, governments in the Visegrad countries managed to establish relatively strong social safety nets. ${ }^{2}$

The question that arises is whether these two models of transition lead to different changes in the distribution of income. In its influential 1996 World Development Report (WDR), the World Bank reports a major increase in per capita income inequality in the NIS, a sizeable increase in some CEE countries (Bulgaria and the Czech Republic), but a very small increase in other CEE countries (Hungary and Slovenia). Between 1987-88 and 1993, the Gini coefficients presented in the WDR increased from the $0.24-0.34$ range to 0.48 in Russia and from 0.19 to 0.27 in the Czech Republic. ${ }^{3}$ In contrast, the corresponding increase in Hungary was from 0.21 to 0.23 and in Poland from 0.25 to 0.30 . The World Bank calculations suggest that, while the NIS experienced a major increase in inequality, the CEE countries registered diverse outcomes.

In this study, we present detailed evidence that income inequality in the Czech Republic did not rise to the extent claimed in the WDR. ${ }^{4}$ We also show that income inequality did not change appreciably in Slovakia from 1989 (before the 'Velvet Revolution') to 1993 (four years into the transition and the year of the 'Velvet Divorce' between the two republics). ${ }^{5}$ The Czech and Slovak Republics continue to have two of the lowest levels of inequality in the world. We postulate that an important stylized fact in the transition process is that the four Visegrad countries, unlike their NIS counterparts, have created market economies with relatively little increase in income inequality.

The two principal questions that we are interested in addressing are: 1) To what extent is the persistent low overall inequality brought about by government policies versus market forces in each republic? 2) Are the effects of these countervailing forces different or similar in the two republics? We begin (in Section 2) by surveying the channels of redistribution: market forces and government policies in the areas of asset redistribution, incomes policies, the social safety net, and taxes. We then probe how these channels influenced the change in overall income inequality over time by examining the change in inequality in each of its principal components: income from labour and capital, government and private transfers, and taxes. The methods and data we use for our analysis are described in Section 3. We present the findings with respect to change in inequality over time within and between republics in Section 4; the conclusions are in Section 5 .

\section{The transition}

The 'Velvet Revolution' in October 1989 ended the period of a Communist command economy and started the transition to a market system in the Czech and Slovak Republics. In this section we briefly describe the salient features in the evolution of the two economies from 1989, when they were part of one federation, to 1993, when they formed two independent republics. We focus on the channels of redistribution, specifically, changes in macroeconomic indicators (Section 2.1) and changes in government policies which influence the distribution of income: privatization of state property (Section 2.2), incomes policies (Section 2.3), the social insurance (Section 2.4), social assistance (Section 2.5) and the new tax system (Section 2.6). We then analyse the effects of these policies in our analysis of changes in income inequality below (Section 4). 


\subsection{Macroeconomic conditions}

The Czech and Slovak divorce on January 1, 1993 is widely believed to have been conditioned by the more negative economic developments in Slovakia than the Czech Republic. The doubledigit unemployment rates in Slovakia and low single-digit rates in the Czech Republic support this view (Table 1). However, other macroeconomic statistics do not show major differences in the evolution of the two economies until 1993, when differences began to appear.

As seen in Table 1, both the Slovak and Czech economies suffered a recession during 199093, with the worst decline in GDP and highest inflation in 1991, the year most prices were liberalized. The annual decline in Slovak GDP was only slightly larger than that of the Czech Republic every year until the year of the Velvet Divorce, when the Slovak GDP fell by 4.7 per cent, while the Czech GDP declined by only 0.3 per cent ${ }^{6}$

The figures in Table 1 show that the level of total employment fell more rapidly in Slovakia, especially in the 1991-93 period. They also indicate that the gap in the Czech-Slovak unemployment rates is much greater than that implied by the gap in the rates of decline of employment and/or output. Part of the missing story is that the statistics for output and employment in Table 1 do not account for small firms (less than 25 workers from 1992 and less than 100 workers during 1989 to 1991), while the unemployment rates include the entire population. It is generally believed that the small private sector firms started to appear earlier in the Czech Republic and grew at a faster rate. If these firms had been incorporated in the employment figures, they would have dampened the decline in employment in the Czech Republic relative to that in the Slovak Republic.

Table 1. Selected macroeconomic statistics for the Czech and Slovak Republics

\begin{tabular}{lccccc}
\hline Annual per cent change in: & $\mathbf{1 9 8 9}$ & $\mathbf{1 9 9 0}$ & $\mathbf{1 9 9 1}$ & $\mathbf{1 9 9 2}$ & $\mathbf{1 9 9 3}$ \\
\hline Real GDP* & & & & & \\
$\quad$ Czech Republic & 4.5 & -1.2 & -14.2 & -6.6 & -0.3 \\
$\quad$ Slovak Republic & 1.1 & -2.4 & -14.0 & -7.0 & -4.7 \\
$\quad$ Total employment (avg. annual) & & & & & \\
$\quad$ Czech Republic & 0.6 & -1.0 & -5.5 & -2.6 & -1.6 \\
$\quad$ Slovak Republic & -0.2 & -0.8 & -7.9 & -5.3 & -4.3 \\
$\quad$ Consumer Price Index (CPI) & 1.4 & 9.7 & 56.7 & 11.1 & 20.8 \\
$\quad$ Czech Republic & 1.3 & 10.4 & 61.2 & 10.1 & 23.2 \\
$\quad$ Slovak Republic & & & & & \\
Average real wage & 0.8 & -5.6 & -25.5 & 10.8 & -0.4 \\
$\quad$ Czech Republic & 1.0 & -5.7 & -27.7 & 9.5 & 0.6 \\
$\quad$ Slovak Republic & & & & & \\
$\quad$ Unemployment rate (level in per cent) & 0.0 & 0.7 & 4.1 & 2.6 & 3.5 \\
$\quad$ Czech Republic & 0.0 & 1.5 & 11.8 & 10.3 & 14.4 \\
$\quad$ Slovak Republic &
\end{tabular}

Sources: Dyba and Svejnar (1995, pp.23-39) and Czech and Slovak Statistical Offices, Statistical Yearbooks. *For firms with more than 100 employees 1989-91 and more than 25 employees 1992-93.

\subsection{Asset redistribution-privatization?}

The method of redistributing assets in the Czech and Slovak Republics was identical until the Velvet Divorce of January 1993, at which time the Slovak government stopped the process and (later) changed the rules of the game. Between 1990 and 1993, privatization was divided into 
three programmes: i) restitution, ii) large-scale privatization; and iii) small-scale privatization. Although a large amount of privatization took place during this period, especially in the Czech Republic, by 1993 capital income was still relatively small and because of the method of asset redistribution, not terribly skewed.

Restitution legalized the return of certain property (mostly buildings and some agricultural land) to its previous owners. By the end of 1991, between 2.5 and 4.5 billion US dollars worth of property (between 2.7 and 4.5 per cent of total fixed assets in the Czech Republic) had been restored to Czech citizens. ${ }^{8}$ The degree of restitution in Slovakia was quite similar. However, given that tenants occupied much of the property and their rent-controlled leases had to be honoured for five years, the return to owners of this property was low.

Large-scale privatization applied to most state-owned firms and was the most important part of the programme in terms of the value of assets, over US $\$ 40$ billion in the Czech Republic and over US $\$ 20$ billion in Slovakia. This represented roughly 41.5 per cent of fixed assets in the Czech Republic in 1991 and 49.1 per cent of fixed assets in Slovakia in 1992. ${ }^{9}$ More than onehalf of the face value of these companies was distributed to the Czech and Slovak populations through a 'voucher privatization' scheme. For the purposes of this study, it is important to note that people did not receive their shares from the first wave of large-scale privatization until 1993. Hence, we would not expect to see large amounts of income from 'stocks and bonds' by 1993.

Small-scale privatization consisted of public auctions of small businesses primarily in retail trade, catering and services. In the Czech Republic a total of 22,212 units were auctioned for $\$ 1.0$ billion by the end of 1992 (with two-thirds sold in 1991). Just 855 units were sold in 1993 . This programme, carried out in both republics, was the first step in creating the small-scale private sector; it clearly impacted the income of small entrepreneurs.

The rapid privatization of enterprises (small and large) also meant that by 1993 a significant part of the labour force was working in the private sector. The proportion of total employment in the private sector in 1993 was considerably higher in the Czech Republic, 53.5 per cent, than in the Slovak Republic, 32.0 per cent (Czech and Slovak Statistical Yearbooks, 1994). This could clearly have implications for the distribution of wages in these two republics.

\subsection{Incomes policies}

\subsubsection{Wage controls}

The extent to which wage controls played a role in compressing wages and or moderating wage growth in these two republics has not been formally analysed. Wage controls were first put into effect in 1991 and then intermittently in the ensuing years, with several changes in design. Although they were in place in 1993, their coverage and scope changed during that year. ${ }^{10}$

When they were in effect, wage controls limited the wage bill growth in an enterprise to equal the product of the total number of employees in the enterprise at the beginning of the year and the economy-wide average wage. Hence, some adjustment of relative wage levels within the enterprise was possible. Moreover, it is not clear how effective wage controls were because fines were not imposed until the enterprise exceeded the norm by five per cent and, in 1992, more profitable firms were allowed to raise their wage bill at a higher rate than the norm.

For most of the period the policy only applied to the large-scale state sector. However, in 1993, the government extended coverage to all enterprises with more than 25 employees. Given that a) the targeted population and goals changed often in a short time period and b) monitoring and enforcement were considered to be weak, it was unlikely that wage controls had a significant effect on wage growth or wage dispersion.

\subsubsection{Minimum wages}

A single minimum wage was established in 1991 for the two republics. In 1993 it was 40 (42) 
per cent of the average economy-wide wage in the Czech (Slovak) Republic. In October 1993, the Slovak government raised the minimum wage so that it became 47 per cent of the average wage, resulting in a level above that which existed in the Czech Republic (see Table 2 for minimum wage levels). The minimum wage increase in Slovakia may have mitigated the increase of wage inequality brought about by market forces in Slovakia relative to that in the Czech Republic, where the minimum was not increased.

\subsection{Social insurance}

The social insurance scheme was multifaceted. Parts of the system existed before the transition while other parts were added later. The two parts that we are most interested in for our analysis of income inequality include the unemployment compensation system and the pension system.

\subsubsection{Unemployment compensation system}

An unemployment compensation system (UCS) did not exist in 1989 (when there was no unemployment) but it played a role in the distribution of income in 1993 by replacing part of lost income for a period of six months. The eligibility criteria, entitlement and replacement rates were the same for the two nations in $1993 .{ }^{11}$ However, the level of benefits rose for some in Slovakia when the minimum wage was raised in October of that year. Unemployment benefits were not taxed, which increased their value relative to earned income. However, since they were not indexed for inflation, their value eroded over the unemployment spell. Unemployment compensation clearly mitigated the widening of the income distribution in each country and likely played a bigger role in Slovakia than in the Czech Republic, ceteris paribus.

\subsubsection{Pension system and early retirement}

In both 1989 and 1993, men could retire with full pensions at the age of 60 . For women the retirement age was between 53 and 57, depending on the number of children raised. In 1989, people could draw their pension and work simultaneously and they could easily retire early with a full pension. However, these options were no longer possible for the Czechs with the passing of a comprehensive 1993 law on pensions. The law introduced a 'work or retire' system and limited early retirement to a maximum of three years before the legal retirement age. Early retirement was discouraged by a) requiring registration as unemployed in the district Labour Office for at least 180 days before early retirement and $b$ ) reducing the benefit level during the early pension years. ${ }^{12}$ Because pensions were indexed for inflation in both republics, the average pension maintained its value over the $1989-93$ period. In 1993 the average old-age pension of 2,367 SK (2,799 CZK) per month was 50.7 (58.5) per cent of the average economy-wide net wage in the Slovak (Czech) Republic. Since pensions are not taxed we compare them to the after-tax wage (see Table 2). The disability pensions were somewhat lower in each republic and the widow's pensions were only about one-quarter of the average net wage.

\subsection{Social assistance system ${ }^{13}$}

Unlike the UCS, the social assistance system existed in 1989. However, several legal changes were made in the 1991-93 period, resulting in a complicated web of legal norms and a wide variety of benefits. One important thrust of these changes was that the number of means-tested benefits increased in 1993 as compared to $1989 .{ }^{14}$ In general terms, transfers in 1993 can be grouped as means-tested social assistance and non-means tested social aid to families with children (family benefits).

\subsubsection{Minimum living standard}

In 1991 the right for everyone to have 'assistance essential for ensuring the basic living conditions' was established. Minimum living standards (MLS) were set for different household 
types and served as a basis for providing means testing. The MLS for each household was computed as a sum of two parts: 1) the personal minimum, based on whether one was an adult or a child, and 2) the household minimum, a function of the number of individuals considered to be living together as a household. Households could receive a cash benefit (social assistance) equal to the difference in their income and the MLS. Until October 1993, the two republics had the same MLS levels. In that month Slovakia raised the MLS levels as a result of the increase in the minimum wage.

In order to assess the level of the social safety net, we compare the average levels of social assistance, pension, and unemployment benefits to the minimum wage and the average economy-wide net wage in $1993 .{ }^{15}$ Because benefits were calculated on the basis of net wages (and benefits were not taxed), we calculate and compare each benefit type to a net wage that we estimated. Using data from the Czech and Slovak Family Budget Surveys, we calculate the ratio of 1993 average household after-tax income to before-tax income and apply this estimate of average tax rates to the economy wide wage (published in the Czech and Slovak Statistical Yearbooks) to estimate the net wage. ${ }^{16}$

The data for our comparison are presented in Table 2. Until October of 1993, the relative levels of the safety net were marginally lower in Slovakia as compared to the Czech Republic. However, in both countries the MLS was relatively high compared to the average unemployment benefit. In the first part of 1993, the average person living alone could receive 36 (41) per cent of the average net wage as social assistance or, if unemployed, 29(33) per cent of the average net wage as an unemployment benefit in the Slovak (Czech) Republic. ${ }^{17}$ The level of social assistance for large families was higher: an average family of four in Slovakia could receive benefits equal to 109-132 per cent of the average net wage and in the Czech Republic this family could receive 129 per cent of the average net wage. For low-wage workers, this was a substantial benefit.

\subsubsection{Social aid to families with children}

Before 1994 (1996) households with children in Slovakia (Czech Republic) were able to receive a package of family benefits irrespective of their level of income. Social support benefits were not taxable, but there was implicit taxation in that these benefits were included as part of total income of a household when applying for social assistance. The most important of these benefits are described below, with amounts provided.

i) Child Allowances were provided from birth to the end of the child's education. The amount of the benefit was a function of the age of the child, ranging from 6 per cent (for a child under six years old) to 9 per cent of the average gross wage (for a child over 15 years old) in 1993. Although each was quite low, a family with four children could have received as much as one-quarter to one-third of the average gross wage as an allowance.

ii) Parental Allowances are payments to a parent personally caring full-time for a child up to three years of age (or up to seven, if the child is handicapped). This benefit was only provided to a non-working parent (except in cases when the net income earned by the parent was less or equal to his/her personal minimum living standard). In 1994 the maximum benefit, defined as a lump sum, was approximately 79 per cent of the minimum wage or 26 per cent of the average economy-wide wage.

iii) Maternity Leave Benefits were provided to working women. They were eligible for 28 weeks of paid leave from their work. The level of the benefit was a function of the woman's previous wage, with a maximum level. The replacement ratio was reduced from 90 per cent in 1991 to 69 per cent in 1994 but the maximum level rose substantially from 1.03 to 1.8 times the minimum wage.

iv) Maternity and Pregnancy Compensation Benefits were provided to women who had to be moved to a lower paying job due to pregnancy or child-care problems. 
Table 2. A comparison of monthly social transfers with the average monthly net wage in the Czech and Slovak Republics, 1993

\begin{tabular}{|c|c|c|c|c|c|c|}
\hline & \multicolumn{4}{|c|}{ Slovak Republic } & \multirow{2}{*}{\multicolumn{2}{|c|}{$\begin{array}{c}\text { Czech Republic } \\
\text { 1/93-12/93 }\end{array}$}} \\
\hline & \multicolumn{2}{|c|}{ 1/93-9/93 } & \multicolumn{2}{|c|}{$10 / 93-12 / 93$} & & \\
\hline & SKK & Index & SKK & Index & CZK & Index \\
\hline Economy-wide wage ${ }^{1}$ & 5,264 & & 5,264 & & 5,459 & \\
\hline Economy-wide 'net' wage ${ }^{2}$ & 4,669 & 100.0 & 4,669 & 100.0 & 4,788 & 100.0 \\
\hline Minimum wage & 2,200 & 47.1 & 2,450 & 52.5 & 2,200 & 46.0 \\
\hline \multicolumn{7}{|l|}{ Unemployment benefit } \\
\hline Average $^{3}$ & 1,360 & 29.1 & 1,360 & 29.1 & 1,585 & 33.1 \\
\hline Maximum $^{4}$ & 3,300 & 70.7 & 3,675 & 78.7 & 3,300 & 68.9 \\
\hline \multicolumn{7}{|l|}{ Minimum living standard for: } \\
\hline One member $\mathrm{HH}$ & 1,700 & 36.4 & 1,980 & 42.4 & 1,960 & 40.9 \\
\hline Two member $\mathrm{HH}^{5}$ & 2,900 & 62.1 & 3,510 & 75.2 & 3,500 & 73.1 \\
\hline Four member $\mathrm{HH}^{6}$ & 5,100 & 109.2 & 6,180 & 132.4 & 6,170 & 128.9 \\
\hline \multicolumn{7}{|l|}{ Average pension ${ }^{7}$ : } \\
\hline Old-age & 2,367 & 50.7 & 2,367 & 50.7 & 2,799 & 58.5 \\
\hline Disability & 2,247 & 48.1 & 2,247 & 48.1 & 2,639 & 55.1 \\
\hline Widow's & 1,255 & 26.9 & 1,255 & 26.9 & 1,192 & 24.9 \\
\hline
\end{tabular}

Sources: Slovak and Czech Republics Ministries of Labour and Statistical Offices.

Notes:

1. Excludes small firms of less than 25 employees-annual average.

2. Based on calculations, using the 1993 Family Budget Survey, of the ratio of average household aftertax income to before-tax income ( 0.886 in Slovakia and 0.877 in the Czech Republic).

3. Calculated as: (total amount of benefits paid out in the year/12)/average number of unemployed and receiving benefits in a month.

4. Maximum for those unemployed who were not taking a retraining course.

5. Household of two adults.

6. Household of two adults and two children aged 6 to 9 years and 10 to 15 years.

7. Average monthly level of pensions for the year.

\subsection{Taxes}

Changes in the tax system were being introduced throughout the $1989-93$ period. However, in 1993 a new comprehensive tax law that introduced two important changes in taxes on income came into effect in both republics. The new tax system included:

i) A more progressive income tax with rates beginning at 15 per cent (for taxable incomes up to 60,000 crowns per annum in both republics) and rising to a maximum of $47 \mathrm{per}$ cent. Taxable income included wages and salaries, self-employment income, rental income, interest income, and dividends. A taxpayer allowance of 20,400 crowns per annum could be deducted in computing taxable income, and there were also exemptions for a spouse and children. Social insurance contributions also became deductible.

ii) A new payroll-based social insurance tax paid partly by employees and partly by employers. The employee plus employer combined rates for pensions, sickness benefits and unemployment insurance were $27.2,4.8$, and 4.0 per cent of gross wages, respectively. 
The new system explicitly separated the tax for social benefits from the new income tax, when in 1989 the tax for social benefits had been part of the wage tax. In their study of the tax system in the two countries, Heady and Smith $(1995, \mathrm{p} .12)$ conclude that: 'The new income tax plus the payroll taxes paid by employees is more progressive than the old wage tax but lthe new income tax] provides smaller child tax allowances. The increased progressivity is a rational response to an expected increase in the degree of pre-tax income inequality, and the reduction in child tax allowances represents a reduction in a level of state support for children that had been very generous by western standards'.

\subsection{Summary}

We compare income inequality in 1989, when the two republics were federated and operated as command economies, to inequality in 1993, when the two republics were separated and had functioned for four years under market forces. The macroeconomic situation during this time can be characterized as including a recession, two years of high inflation and a decline in the real wage level. We note that in 1993 market forces may have contributed to the divergence of inequality in the two countries, by creating more unemployment in Slovakia and more private sector employment in the Czech Republic. We do not expect income from stocks to be very large or to contribute greatly to inequality since people were just receiving their income from the first round of voucher privatization at the end of 1993. The governments' wage policies may have had an equalizing effect by not allowing wages to rise more rapidly and by creating a minimum wage floor. The increase in the minimum wage in Slovakia in October could have improved incomes there relative to incomes in the Czech Republic, where the minimum wage was not increased. The higher minimum wage also meant a higher social safety net in Slovakia compared to the Czech Republic as it raised the minimum living standard and social assistance associated with it. Since the other components of social assistance (e.g. social aid to families) were not as yet targeted to the poor in 1993, we do not expect them to have been important in mitigating the growth of inequality over time. Changes in social insurance should have dampened the rate of growth of inequality in the two countries, by protecting the income of pensioners and the unemployed, especially in the Slovak Republic where the incidence of unemployment was higher. Finally, based on revisions to the tax law, we expect taxes to contribute more to lowering overall after-tax income inequality in 1993 than in 1989 . We proceed to examine whether these expectations are borne out by the data.

\section{Methods and data}

\subsection{The data}

The analysis in this paper is based on data from the 1989 and 1993 Family Budget Surveys (FBS) of the Czech and Slovak Republics. These data have been collected annually by the Central Statistical Offices in each country for over three decades. For our purposes, the basic strengths of the FBS are the years for which data are available and the frequency of data collection. The FBS are the only comparable data sets available for analysis of income inequality in the two republics in 1989 and 1993. The other databases used for income distribution studies are the Czech and Slovak Republics' Microcensuses, which are most currently available for 1988 and 1992. Since we are interested in comparing a pre-transition period with a period after the two republics divided, the Microcensus data are not appropriate for our study. In contrast to the Microcensus, which gathers data at one point in time, the FBS data are collected each month of each year. ${ }^{18}$ In the Microcensus, single month recall data is used to produce annualized values for some types of income. In the FBS, annual incomes are 
produced by adding monthly incomes recorded by the household. This clearly improves the reliability of the income data.

The FBS data are not strictly representative of the total population whereas the Microcensus data are. To deal with this problem, we apply to the FBS data, household population ratioadjusted weights created from the 1988 and 1992 Microcensus data. Households in the FBS and Microcensuses were matched by region of residence, social group, and family size to create the weights. If there were shifts in the population from 1988 to 1989 and from 1992 to 1993 as defined by these variables, the inequality results could differ. Reweighting the data however does not entirely resolve the representativeness problem. For example, we could not account for households in the population that are not included in both years of the FBS sample, specifically:

(i) those headed by pensioners but in which there were other economically active members and (ii) those headed by non-working persons including the unemployed. (Although households in which the head had been working at the time of sample selection but then became unemployed during the survey period could have remained in the 1993 sample.). ${ }^{19}$

The FBS has also been criticized for not adequately reflecting incomes for households at the extreme ends of the distribution (Bednarik 1998; Večerník 1996). This is a criticism of most expenditure and income surveys in which over-sampling of the extremes has not been conducted. Thus the inequality results using the FBS data may underestimate the inequality in income for the total population. Because we are focusing on changes over time, we believe these concerns are less important for our research.

For our analysis, we use data from the primary FBS file. For 1989, our sample includes 3,974 households (roughly 10,500 persons) in the Czech Republic and 1,696 households (with about 5,100 people) in Slovakia. For 1993, the sample consists of 3,422 households (about 9,000 people) in the Czech Republic and 1,778 households (5,100 people) in Slovakia. ${ }^{20}$ There was an average of 2.6 persons in Czech households in 1989 and 1993. In contrast, Slovak households tended to be larger with 3.0 persons per household in both years. This is in part due to the fact that Slovak households had more children in them than Czech households. ${ }^{21}$ The average number of earners per household in Slovakia was slightly higher than in the Czech Republic for both years. However, the average number of earners in each republic fell from 1989 to 1993: for the Czech Republic the average number fell from 1.3 to 1.2 and for Slovakia the average fell from 1.4 to 1.2 .

The percentages of households that were receiving government transfers of any kind, except pensions, were very high and rose substantially from 1989 to 1993: from 63.3 per cent to 91.6 per cent in the Czech Republic, and from 67.9 per cent to 91.1 per cent in Slovakia. The percentages of households with pension income also grew, from 37.0 per cent to 39.5 per cent in the Czech Republic and from 31.1 per cent to 36.7 per cent in Slovakia.

\subsection{Variables of interest}

The components of income that are of most interest to us include the following:

- Earned income

1. Earnings from any type of work, including agricultural self-employment (henceforth, 'wage income') 22

2. Earnings from non-agricultural self-employment, only available in 1993 (henceforth, 'self-employment income') ${ }^{23}$

3. Other monetary income, which includes returns on stocks and bonds and other cash money incomes (e.g. from insurance $)^{24}$

\section{- Other income}

4. In-kind consumption ${ }^{25}$

5. Private cash transfers (including monetary gifts from relatives and support of a social character from private organizations) 
- Government transfers

6. Pensions

7. Other government transfers which include:

- Sickness-related benefits (which include income from health insurance and financial support while taking care of a family member, and financial aid during maternity and maternity leave);

- Unemployment benefits (in 1993 only)

- Child allowances

- Social assistance and other family benefits (including parental allowances, other family benefits and other income for persons with social needs) ${ }^{26}$

- Taxes:

8. Income taxes (wage tax in 1989)

9. Other taxes (social payroll taxes plus all other taxes-real estate taxes, fees, and fines).

\subsection{Inequality measurement and decomposition}

Our analysis of income inequality uses the standard Gini coefficient $(G)$ and the Lerman and Yitzhaki $(1985,1989,1994)$ source decomposition method. ${ }^{27}$ The analysis takes account of the fact that we have population-stratified samples with household level data. The observation unit is the household and is defined as a group of individuals living together and sharing expenditures for food, housekeeping, home maintenance, and other commodities. To account for differences in household size, we divide each household's income by the number of equivalent adults in the household. We use the scale adjustment factors proposed by the OECD (1982). The result is the adult equivalent household income $(Y)$ computed as:

$$
Y=\frac{X}{\left(1+0.7^{*} A+0.5 * C\right)}
$$

where: $X=$ household income;

$A=$ number of adults other than the reference person;

$C=$ number of children.

Since the focus of our research is the economic well-being of individuals, we allocated the adult equivalent income values to each person in the household. This weighting results in the individual distribution rather than the household distribution of incomes. This procedure was used for all income components and for total after-tax income.

The Gini decomposition approach developed by Lerman and Yitzhaki $(1985,1989,1994)$ allows us to examine: a) the percentage contribution of a particular income component to overall inequality; b) the marginal impact on overall income inequality of a component; and c) how changes in the components over time have affected changes in overall inequality. The Gini for total after-tax income $\left(G_{y}\right)$ is based on the product of three terms for each component $i$ : the component's share of after-tax income $\left(S_{i}\right)$, its inequality $\left(G_{i}\right)$, and the correlation between the rank of after-tax income and the level of the component $\left(R_{i}\right):^{28}$

$$
G_{y}=\sum_{i=1}^{m} S_{i} R_{i} G_{i},
$$

where $m=$ the number of income components. Each of the three terms is computed for the income components for each republic and in both years, 1989 and 1993. 
To produce the percentage contribution of an income component to after-tax income inequality $\left(P_{i}\right)$, we divide the contribution of the income component from equation (2) by $G_{y}$ and multiply by 100 :

$$
P_{i}=\frac{S_{i} R_{i} G_{i}}{G_{y}} * 100
$$

As an example, let us assume we want to focus on the four aggregate income components listed in Section 3.2 above: earnings $(e)$, other income $(o)$, government transfers $(t r)$, and taxes $(t x)$. Because we are interested in after-tax income, the share of taxes enters our equation as a negative value, $S_{t x}<0$. For our four major income components,

$$
100=P_{e}+P_{o}+P_{t r}-P_{t x}
$$

In addition to learning which components account for greater or lesser overall inequality, we examine the extent to which a marginal increase in one component would be likely to increase or decrease overall inequality. For example, we examine whether a marginal increase in taxes might have a greater or lesser effect on reducing overall inequality than would a marginal increase in transfers. Following Lerman and Yitzhaki (1994), the marginal effect of a small change in income component $i$ on $G_{y}$, holding all other factors constant, is

$$
Z_{i}=S_{i} R_{i} G_{i}-S_{i} G_{y}
$$

Finally, in order to learn which of these income components have accounted for the change in inequality over time within each republic, the absolute change from 1989 to 1993 in the Gini is decomposed into changes in each component $i$ :

$$
G_{y 93}-G_{y 89}=\sum_{i=1}^{m}\left(S_{i} R_{i} G_{i}\right)_{93}-\sum_{i=1}^{m}\left(S_{i} R_{i} G_{i}\right)_{89}
$$

This demonstrates how the change in the Gini over time is affected by changes in each component's share of total after-tax income, its inequality, and its correlation with the rank of after-tax income. We then calculate the differences between the Czech Republic's and Slovakia's differences over time.

\section{Findings}

As indicated in the introduction, we find that disposable income inequality increased very little from 1989 to 1993 . The Gini coefficient rose 0.012 points (from 0.162 to 0.174 ) in the Czech Republic and 0.011 points (from 0.157 to 0.168 ) in Slovakia. The difference between each republic's Ginis over time is statistically significant (at the $\alpha=0.01$ level for the Czech Republic and at the $\alpha=0.05$ level for Slovakia). ${ }^{29}$ Although the coefficients show consistently higher inequality in the Czech Republic, the differences in the Gini coefficients for the Czech Republic and Slovakia are not statistically significant in either 1989 or $1993 .^{30}$

The finding that inequality rose so little during these first four years, given how rapidly the two countries were making the transition to a market-oriented economy, may seem surprising, 
especially when one considers the rapid increase in inequality in Russia and some of the NIS. ${ }^{31}$ Was it that wage inequality did not rise as much in the Czech and Slovak Republics? Perhaps the social safety nets in the Czech and Slovak Republics were effective in lessening the impact of market forces. In order to understand the change in inequality over time, we first decompose the after-tax income Gini coefficient for each country and in each year by income components (see equation 2). The $S_{i,}, R_{i}, G_{i}$, are shown in Tables 3 and 4 for the Czech and Slovak Republics, respectively. Using these results, we calculate the percentage contribution of each component to overall inequality $\left(P_{i}\right)$, presented in Table 5 . We follow this with an analysis of the marginal effects of each component $\left(Z_{i}\right)$, shown in Table 6 . Finally, we examine the extent to which changes in each income component can account for the change in the overall Gini over time within each country and between each country (see equation 6). These results are found in Table 7.

To aid the reader in interpreting the findings in Tables 5-7, we note that a negative sign on the value indicates that the component is having an equalizing effect on total income inequality and a positive sign is having an unequalizing effect. Moreover, for each table, three different levels of aggregation of total after-tax income are presented, corresponding to the definition of income components in Section 3.2. The most aggregated grouping is in bold and the other levels of disaggregation are progressively indented.

\subsection{Contribution of each component to total income inequality $\left(P_{i}\right)$}

The most outstanding result from examining the percentage contributions shown in Table 5, is the extent to which the earnings component, primarily wages, is contributing to overall inequality in each republic and in each year. In 1989, earnings account for 130.5 and $133.6 \mathrm{per}$ cent of total inequality in the Czech and Slovak Republics, respectively. As seen in Tables 3 and 4 , this outcome is primarily due to the wage component's contribution and this results from wages' relatively large share of total after-tax income $\left(S_{w}\right)$ and its high correlation with total after-tax income $\left(R_{w}\right)$, but not to the inequality of wages in 1989. (Although $G_{w}$ is about 1.8 times $G_{y}$, the ratios of the other $G_{i}$ s to $G_{y}$ are even larger.) As expected, the earnings component contributes even more to the overall Gini in 1993 than it does in 1989: 155.0 per cent in the Czech Republic and 142.9 per cent in Slovakia. Wages continue to be the lion's share of this component, but the new self-employment income component begins to play a role. In the Czech Republic, the contributions of both wages and other earned income (including self-employment income) increase in 1993 compared to 1989, whereas in Slovakia only other earned income increases its contribution; the wage contribution remains unchanged. The new component, earnings from self-employment, explains a higher share of the Slovak Gini (11.4 per cent) than the Czech Gini (9.2 per cent). The percentage of the Gini explained by insurance, stocks and bonds remains about the same in the Czech Republic and falls in Slovakia by 1993. We note that the overall importance of in-kind consumption plus private cash transfers fell in 1993, relative to 1989 in both republics. The increase in $G_{y}$ arising from an increase in the earnings component is driven largely by the increase in the inequality of earnings $\left(G_{e}\right)$ in both republics, which is due to a substantial increase in $G_{w}$ and a very high $G_{\text {self-emp }}$ in each republic. Changes in $S_{e}$ and $R_{e}$ also contribute to a larger earnings component in the Czech Republic, but not in Slovakia. (See Tables 3 and 4.) 
Table 3. Components of Gini Index decomposition of after-tax income in the Czech Republic, 1989 and 1993*

\begin{tabular}{|c|c|c|c|c|c|c|}
\hline \multirow[t]{2}{*}{ Income component } & \multicolumn{3}{|c|}{1989} & \multicolumn{3}{|c|}{1993} \\
\hline & $\begin{array}{c}\text { Share of } \\
\text { total } \\
\text { income } \\
\left(S_{i}\right)\end{array}$ & $\begin{array}{l}\text { Gini corre- } \\
\text { lation }\left(\boldsymbol{R}_{i}\right)\end{array}$ & $\begin{array}{c}\text { Component's } \\
\text { Gini }\left(G_{i}\right)\end{array}$ & $\begin{array}{c}\text { Share of } \\
\text { total } \\
\text { income } \\
\left(S_{i}\right)\end{array}$ & $\begin{array}{c}\text { Gini } \\
\text { corre- } \\
\text { lation }\left(R_{i}\right)\end{array}$ & $\begin{array}{c}\text { Component's } \\
\text { Gini }\left(G_{i}\right)\end{array}$ \\
\hline Earnings & 0.852 & 0.836 & 0.297 & 0.863 & 0.859 & 0.363 \\
\hline wage income & 0.815 & 0.799 & 0.301 & 0.776 & 0.767 & 0.399 \\
\hline other earned income & 0.037 & 0.526 & 0.820 & 0.087 & 0.439 & 0.845 \\
\hline $\begin{array}{l}\text { self-employment } \\
\text { income }\end{array}$ & & & & 0.052 & 0.328 & 0.934 \\
\hline $\begin{array}{l}\text { insurance, stocks } \\
\text { and bonds }\end{array}$ & 0.037 & 0.526 & 0.820 & 0.034 & 0.560 & 0.840 \\
\hline Other income & 0.079 & 0.430 & 0.534 & 0.070 & 0.374 & 0.552 \\
\hline in-kind consumption & 0.062 & 0.367 & 0.523 & 0.057 & 0.330 & 0.552 \\
\hline private cash transfers & 0.018 & 0.429 & 0.840 & 0.013 & 0.363 & 0.852 \\
\hline Government transfers & 0.201 & -0.311 & 0.508 & 0.228 & -0.478 & 0.511 \\
\hline pensions & 0.113 & -0.312 & 0.827 & 0.126 & -0.475 & 0.804 \\
\hline social benefits & 0.088 & -0.064 & 0.482 & 0.102 & -0.192 & 0.386 \\
\hline sickness benefits & 0.024 & 0.244 & 0.771 & 0.019 & 0.293 & 0.791 \\
\hline child allowances & 0.057 & -0.193 & 0.493 & 0.034 & -0.086 & 0.498 \\
\hline unemployment & & & & 0.001 & -0.072 & 0.982 \\
\hline other social benefits & 0.007 & -0.277 & 0.905 & 0.048 & -0.450 & 0.486 \\
\hline Taxes & -0.133 & 0.673 & 0.401 & -0.161 & 0.780 & 0.432 \\
\hline income tax & -0.130 & 0.665 & 0.407 & -0.065 & 0.791 & 0.496 \\
\hline other taxes & -0.003 & 0.310 & 0.765 & -0.096 & 0.748 & 0.401 \\
\hline social payroll taxes & & & & -0.093 & 0.746 & 0.406 \\
\hline other taxes and fees & -0.003 & 0.310 & 0.765 & -0.003 & 0.270 & 0.766 \\
\hline Total after-tax income & 1.000 & 1.000 & 0.162 & 1.000 & 1.000 & 0.174 \\
\hline \multicolumn{3}{|c|}{ Jackknife standard errors of Gini } & 0.002 & & & 0.003 \\
\hline
\end{tabular}

Source: Authors' own calculations from the Family Budget Surveys for the Czech and Slovak Republics. *OECD (1982) scale adjustment, weighted by persons. 
Table 4. Components of Gini Index decomposition of after-tax income in the Slovak Republic, 1989 and 1993*

\begin{tabular}{|c|c|c|c|c|c|c|}
\hline \multirow[t]{2}{*}{ Income component } & \multicolumn{3}{|c|}{1989} & \multicolumn{3}{|c|}{1993} \\
\hline & $\begin{array}{c}\text { Share of } \\
\text { total } \\
\text { income } \\
\left(S_{i}\right)\end{array}$ & $\begin{array}{l}\text { Gini corre- } \\
\text { lation }\left(R_{i}\right)\end{array}$ & $\begin{array}{c}\text { Component's } \\
\text { Gini }\left(G_{i}\right)\end{array}$ & $\begin{array}{c}\text { Share of } \\
\text { total } \\
\text { income } \\
\left(S_{i}\right)\end{array}$ & $\begin{array}{c}\text { Gini } \\
\text { corre- } \\
\text { lation }\left(\boldsymbol{R}_{i}\right)\end{array}$ & $\begin{array}{c}\text { Component's } \\
\text { Gini }\left(G_{i}\right)\end{array}$ \\
\hline Earnings & 0.865 & 0.861 & 0.281 & 0.834 & 0.838 & 0.344 \\
\hline wage income & 0.836 & 0.840 & 0.283 & 0.773 & 0.769 & 0.360 \\
\hline other earned income & 0.029 & 0.425 & 0.833 & 0.061 & 0.496 & 0.883 \\
\hline $\begin{array}{l}\text { self-employment } \\
\text { income }\end{array}$ & & & & 0.039 & 0.514 & 0.963 \\
\hline $\begin{array}{l}\text { insurance, stocks } \\
\text { and bonds }\end{array}$ & 0.029 & 0.425 & 0.833 & 0.023 & 0.411 & 0.829 \\
\hline Other income & 0.073 & 0.458 & 0.554 & 0.084 & 0.400 & 0.531 \\
\hline in-kind consumption & 0.056 & 0.370 & 0.552 & 0.073 & 0.388 & 0.543 \\
\hline private cash transfers & 0.017 & 0.481 & 0.863 & 0.012 & 0.271 & 0.839 \\
\hline Government transfers & 0.191 & -0.434 & 0.459 & 0.226 & -0.407 & 0.469 \\
\hline pensions & 0.088 & -0.410 & 0.860 & 0.110 & -0.386 & 0.838 \\
\hline social benefits & 0.104 & -0.161 & 0.431 & 0.116 & -0.163 & 0.398 \\
\hline sickness benefits & 0.018 & 0.190 & 0.782 & 0.023 & 0.164 & 0.769 \\
\hline child allowances & 0.078 & -0.220 & 0.440 & 0.046 & -0.186 & 0.462 \\
\hline unemployment & & & & 0.004 & 0.026 & 0.955 \\
\hline other social benefits & 0.008 & -0.328 & 0.912 & 0.042 & -0.366 & 0.426 \\
\hline Taxes & -0.130 & 0.648 & 0.395 & -0.145 & 0.806 & 0.403 \\
\hline income tax & -0.128 & 0.645 & 0.398 & -0.061 & 0.792 & 0.487 \\
\hline other taxes & -0.002 & 0.215 & 0.865 & -0.084 & 0.764 & 0.367 \\
\hline $\begin{array}{l}\text { social payroll } \\
\text { taxes }\end{array}$ & & & & -0.082 & 0.760 & 0.376 \\
\hline $\begin{array}{l}\text { other taxes and } \\
\text { fees }\end{array}$ & -0.002 & 0.215 & 0.865 & -0.002 & 0.091 & 0.768 \\
\hline Total after-tax income & 1.000 & 1.000 & 0.157 & 1.000 & 1.000 & 0.168 \\
\hline \multicolumn{3}{|c|}{ Jackknife standard errors of Gini } & 0.004 & & & 0.004 \\
\hline
\end{tabular}

Source: Authors' own calculations from the Family Budget Surveys for the Czech and Slovak Republics. *OECD (1982) scale adjustment, weighted by persons. 
Table 5. Percentage contributions of income components $\left(P_{i}\right)$ to total after-tax income inequality*

\begin{tabular}{|c|c|c|c|c|}
\hline \multirow[t]{2}{*}{ Income component } & \multicolumn{2}{|c|}{ Czech Republic } & \multicolumn{2}{|c|}{ Slovak Republic } \\
\hline & 1989 & 1993 & 1989 & 1993 \\
\hline Earnings & 130.5 & 155.0 & 133.6 & 142.9 \\
\hline wage income & 120.7 & 136.5 & 127.1 & 127.0 \\
\hline other earned income & 9.8 & 18.5 & 6.6 & 15.9 \\
\hline self-employment income & & 9.2 & & 11.4 \\
\hline insurance, stocks and bonds & 9.8 & 9.3 & 6.6 & 4.6 \\
\hline Other income & 11.2 & 8.3 & 11.9 & 10.7 \\
\hline in-kind consumption & 7.3 & 5.9 & 7.4 & 9.1 \\
\hline private cash transfers & 3.9 & 2.4 & 4.5 & 1.6 \\
\hline Government transfers & -19.7 & -32.1 & -24.3 & -25.7 \\
\hline pensions & -18.0 & -27.8 & -19.7 & -21.2 \\
\hline social benefits & -1.7 & -4.3 & -4.6 & -4.5 \\
\hline sickness benefits & 2.8 & 2.5 & 1.7 & 1.7 \\
\hline child allowances & -3.3 & -0.8 & -4.8 & -2.3 \\
\hline unemployment & & -0.1 & & 0.1 \\
\hline other social benefits & -1.1 & -6.0 & -1.5 & -3.9 \\
\hline Taxes & -22.1 & -31.2 & -21.2 & -27.9 \\
\hline income tax & -21.6 & -14.7 & -21.0 & -14.0 \\
\hline other taxes & -0.5 & -16.6 & -0.2 & -14.0 \\
\hline social payroll taxes & & -16.2 & & -13.9 \\
\hline other taxes and fees & -0.5 & -0.4 & -0.2 & -0.1 \\
\hline Total after-tax income & 100.0 & 100.0 & 100.0 & 100.0 \\
\hline Gini & 0.162 & 0.174 & 0.157 & 0.168 \\
\hline
\end{tabular}

Source: See Tables 3 and 4.

*OECD (1982) scale adjustment, weighted by persons.

The values presented for transfers and taxes in Table 5 indicate that these sources make sizeable contributions towards reducing overall inequality. In 1989, their combined contributions are larger in Slovakia $(-45.5)$ than in the Czech Republic $(-41.8)$. Whereas taxes' negative contribution to overall inequality is about the same in the two republics (slightly higher in the Czech Republic), transfers appear to have a greater role in reducing overall inequality in Slovakia ( -24.3 per cent) than they do in the Czech Republic ( -19.7 per cent). This is due to the greater impact of pension income and child allowances in Slovakia in 1989.

Transfers plus taxes have a greater equalizing effect in 1993 than they do in 1989 in both republics, and more in the Czech Republic ( -63.3 per cent) than in Slovakia $(-53.6$ per cent). The relative importance of taxes versus transfers switches in each republic over time. In Slovakia taxes play a greater role than transfers do in 1993, whereas transfers are more important than taxes in 1989; the reverse is true for the Czech Republic. 
In 1993, the contribution of government transfers to overall inequality is smaller in Slovakia ( -25.7 per cent) compared to the Czech Republic ( -32.1 per cent). The difference between the republics is primarily due to the difference in the contributions of pension income, which in 1993 is much larger for the Czech Republic. Social benefits play a relatively small role. Sickness benefits do not reduce inequality in either republic since they are proportional to wages. The contribution of child allowances is equalizing in both republics; it falls over time since its share of total income $(S)$ falls. In 1993, unemployment benefits reduce inequality slightly in the Czech Republic but contribute to inequality in Slovakia. Unemployment benefits are positively correlated with adult equivalent household income in Slovakia (i.e. $R$ of unemployment benefits is positive in Slovakia) rather than negatively correlated, as in the Czech Republic. One interpretation of this surprising result is that unemployed people are living in wealthier households in Slovakia but are concentrated in poorer households in the Czech Republic. Finally, 'other social benefits' which in 1993 include social assistance to meet the minimum living standard, grows in importance over time and contributes to a 6.0 (3.9) per cent reduction in inequality in the Czech (Slovak) Republic in 1993.

The equalizing contribution of taxes increases to -31.2 per cent in the Czech Republic and 27.9 per cent in Slovakia in 1993. The tax contribution is larger in the Czech Republic than in Slovakia because the contribution of other taxes, especially social payroll taxes, is larger. Although it appears that the importance of income taxes in reducing the overall Gini falls in 1993 compared to 1989 , for both republics, care must be taken in interpreting these results. As seen from Tables 3 and 4, the share of taxes paid as income tax falls with the introduction of social payroll taxes. We remind the reader that in 1989 the 'income tax' implicitly included 'payments for social benefits' and in 1993 the two components were explicitly separated. If the contributions of the two types of tax are added together, their overall contribution is larger in 1993 than the contribution of 'income taxes' in 1989 for each republic, which is consistent with Heady and Smith's (1995) statement, referred to previously.

\subsection{Marginal impact $\left(Z_{i}\right)$}

Up to this point, we have formed a static comparison of each component's contribution to inequality (within and between the two republics). However, a more interesting question from a policy perspective may be how a marginal change in a particular source might influence the distribution of overall income inequality. For example, would a government achieve a similar reduction in overall inequality from a small increase in transfers as with a small increase in taxes? To answer this question we use equation 5. Based on our analysis in Table 6, the answer is categorically 'no'. In each country and in both years, a marginal increase in transfers reduces overall inequality much more (by -0.065 to -0.096 points) than a marginal increase in taxes $\left(-0.013\right.$ to -0.026 points). The contributions $\left(S_{i} R_{i} G_{i}\right)$ of transfers and taxes to overall inequality are quite similar to each other within a year for each republic (Table 5). Since the $S_{i} R_{i} G_{i}$ term is the first component of equation 5 , it is clear that differences in the second component, $S_{i} G_{y}$, are driving the marginal results. Note that $S_{t r}>0$ and $S_{t x}<0$ and that $S_{i} G_{y}$ is subtracted from a $-S_{i} R_{i} G_{i}$ (since both tax and transfer contributions are negative). Hence $-S_{r r} R_{t r} G_{t r}-S_{t r} G_{y}<-S_{t x} R_{t x} G_{t x}-\left(-S_{t x} G_{y}\right)$ i.e. a marginal change in transfers has a larger equalizing effect than a marginal change in taxes. The results presented in Table 6 also reveal that a marginal change in earnings would exert the greatest influence on overall inequality for both countries for both years. 
Table 6. Marginal changes in total after-tax income inequality $\left(Z_{i}\right)$ by income component*

\begin{tabular}{lcccc}
\hline Income component & \multicolumn{2}{c}{ Czech Republic } & \multicolumn{2}{c}{ Slovak Republic } \\
& $\mathbf{1 9 8 9}$ & $\mathbf{1 9 9 3}$ & $\mathbf{1 9 8 9}$ & $\mathbf{1 9 9 3}$ \\
\hline Earnings & $\mathbf{0 . 0 7 3}$ & $\mathbf{0 . 1 2 0}$ & $\mathbf{0 . 0 7 4}$ & $\mathbf{0 . 1 0 0}$ \\
$\quad$ wage income & 0.064 & 0.102 & 0.068 & 0.084 \\
other earned income & 0.010 & 0.017 & 0.006 & 0.017 \\
$\quad$ self-employment income & & 0.007 & & 0.013 \\
$\quad$ insurance, stocks and bonds & $\mathbf{0 . 0 1 0}$ & 0.010 & 0.006 & $\mathbf{0 . 0 0 4}$ \\
Other income & $\mathbf{0 . 0 0 5}$ & $\mathbf{0 . 0 0 2}$ & $\mathbf{0 . 0 0 7}$ & $\mathbf{0 . 0 0 4}$ \\
in-kind consumption & $\mathbf{0 . 0 0 2}$ & 0.000 & 0.003 & $\mathbf{0 . 0 0 3}$ \\
private cash transfers & 0.003 & 0.002 & 0.004 & 0.001 \\
Government transfers & $-\mathbf{0 . 0 6 5}$ & $-\mathbf{0 . 0 9 6}$ & $-\mathbf{0 . 0 6 8}$ & $-\mathbf{0 . 0 8 1}$ \\
pensions & -0.047 & -0.070 & -0.045 & -0.054 \\
social benefits & -0.017 & -0.025 & -0.023 & -0.027 \\
$\quad$ sickness benefits & 0.001 & 0.001 & 0.000 & -0.001 \\
$\quad$ child allowances & -0.015 & -0.007 & -0.020 & -0.012 \\
$\quad$ unemployment & & 0.000 & & -0.001 \\
$\quad$ other social benefits & -0.003 & -0.019 & -0.004 & -0.014 \\
$\quad$ Taxes & $-\mathbf{0 . 0 1 4}$ & -0.026 & $-\mathbf{0 . 0 1 3}$ & $\mathbf{- 0 . 0 2 3}$ \\
income tax & -0.014 & -0.014 & -0.013 & -0.013 \\
other taxes & 0.000 & -0.012 & 0.000 & -0.009 \\
$\quad$ social payroll taxes & & -0.012 & & -0.010 \\
$\quad$ other taxes and fees & 0.000 & 0.000 & 0.000 & 0.000 \\
\hline
\end{tabular}

Source: See Tables 3 and 4.

*OECD (1982) scale adjustment, weighted by persons.

\subsection{Decomposition of the change in inequality over time}

What was the relative impact of 1989-93 changes in the income components on the growth in overall inequality within each country and between the two countries? The decomposition of the change in the Gini over time is presented in columns two and three of Table 7. Although the increase in the overall Gini coefficient is almost identical in both countries, different factors are driving the outcome within each republic. Changes in the earnings component clearly contributed to the increased Gini in each republic. However, within Slovakia, changes in the tax component played a greater role than changes in transfers in moderating the growth of inequality. The opposite is true in the Czech Republic, where transfers played a greater moderating role.

The contribution of the earnings component to the growth of overall inequality is substantially greater in the Czech Republic, where earnings account for 0.058 points of the change, compared to 0.031 points in Slovakia. Because the overall Ginis increased by nearly identical amounts (0.011 in Slovakia and 0.012 in the Czech Republic), the sum of changes in other income, taxes, and transfers must have a larger equalizing effect on the Gini in the Czech Republic than it does in Slovakia. As seen from the fourth column of Table 7, changes in each of these three components have a larger equalizing (negative) effect in the Czech Republic: the change in 'other income' reduces the change in the overall Gini by 0.003 points more in the 
Czech Republic than in Slovakia and the change in taxes reduces the change in the Gini by 0.005 points more in the Czech Republic. The greatest difference is in transfers, which reduces the Gini by -0.019 more points in the Czech Republic than in Slovakia. Much of the reason for this larger effect is due to pension incomes having a larger (more negative) marginal effect in the Czech Republic by 1993 relative to 1989.

Table 7. Accounting for the change in the Gini from 1989 to 1993 by income component*

\begin{tabular}{lccc}
\hline Income component & $\begin{array}{c}\text { Czech Republic } \\
(\text { CR })\end{array}$ & $\begin{array}{c}\text { Slovak Republic } \\
(\text { SR })\end{array}$ & CR-SR \\
\hline Earnings & $\mathbf{0 . 0 5 8}$ & $\mathbf{0 . 0 3 1}$ & $\mathbf{0 . 0 2 6}$ \\
wage income & 0.042 & 0.015 & 0.027 \\
other earned income & 0.016 & 0.016 & 0.000 \\
$\quad$ insurance, stocks and bonds & 0.000 & -0.003 & 0.003 \\
Other income & $-\mathbf{0 . 0 0 4}$ & $-\mathbf{0 . 0 0 1}$ & $\mathbf{- 0 . 0 0 3}$ \\
in-kind consumption & -0.002 & 0.004 & -0.005 \\
private cash transfers & -0.002 & -0.004 & 0.002 \\
Government transfers & $-\mathbf{0 . 0 2 4}$ & $-\mathbf{0 . 0 0 5}$ & $\mathbf{- 0 . 0 1 9}$ \\
pensions & -0.019 & -0.005 & -0.014 \\
social benefits & -0.005 & 0.000 & -0.005 \\
$\quad$ sickness benefits & 0.000 & 0.000 & 0.000 \\
$\quad$ child allowances & 0.004 & 0.004 & 0.000 \\
$\quad$ other social benefits & -0.009 & -0.004 & -0.004 \\
Taxes & $\mathbf{- 0 . 0 1 8}$ & $-\mathbf{0 . 0 1 4}$ & $\mathbf{- 0 . 0 0 3}$ \\
income tax & 0.010 & 0.009 & 0.000 \\
other taxes & -0.028 & -0.023 & -0.005 \\
$\quad$ other taxes and fees & 0.000 & 0.000 & 0.000 \\
Total after-tax income & $\mathbf{0 . 0 1 2}$ & $\mathbf{0 . 0 1 1}$ & $\mathbf{0 . 0 0 1}$ \\
\hline
\end{tabular}

Source: See Tables 3 and 4.

Note: Differences due to rounding.

*OECD (1982) scale adjustment, weighted by persons.

How do these decomposition results compare with the findings of others for the NIS and other CEE countries? To answer this question we refer to a recent study by Milanovic (1997) in which he uses a similar methodology to examine after-tax income inequality in six transition economies: Bulgaria (1989-95), Poland (1987-95), Slovenia (1987-95), Hungary (1987-93), Russia (1989-94) and Latvia (1989-96). His decomposition of the change in the Gini coefficient is not strictly comparable to ours since a) he uses per capita incomes; b) the type of decomposition differs; and c) the two years of comparison (indicated in parentheses after each country) are further apart than are ours. With this in mind, it is still clear that changes in the contribution of wages to changes in the overall Ginis pre- and post-transition were much greater in Russia and Latvia than in the other four countries in the Milanovic study, and much greater than in the Czech Republic and Slovakia when our findings are compared to his. 


\section{Summary and conclusions}

Our study has found that in the first four years of the transition, income inequality in the Czech Republic has risen much less than is claimed in the World Bank's 1996 World Development Report. On the basis of our results and a rapidly growing literature we claim that an important stylized fact of the early transition process is that the Visegrad countries were able to create market economies with a smaller increase in income inequality than their NIS counterparts. ${ }^{32}$

Focusing on the Czech and Slovak Republics, we find from the Family Budget Surveys that the Gini coefficient of after-tax income inequality rose in the two countries by similarly small amounts from 1989 to 1993. In accounting for the small overall increases in inequality over time, we find from a Gini decomposition that they resulted from two countervailing effects. In particular, we find that the creation of labour markets and self-employment contributed considerably to increases in the Gini coefficients over time, although perhaps not to the same extent as in Russia and Latvia. However, government policies, specifically the tax and transfer system, reduced the income inequality generated by the introduction of the market system. We find that the relative impact of taxes and transfers differed in the two republics. In the Czech Republic, the changes in the transfer component contributed more than changes in the tax component to the reduction in the growth of inequality. The reverse is true in Slovakia, where changes in the tax component were more important. Among the transfers, it was the protection of pensioners' incomes that made this policy so effective, especially in the Czech Republic. However, the introduction of a 'minimum living standard' also seems to have played a part in mitigating the increase in inequality by upholding the incomes of the poor.

It is also interesting to note that although the overall change in inequality was nearly identical in the two republics, the magnitude of the principal offsetting forces was greater in the Czech Republic than in Slovakia. Hence, the Czech Republic experienced a greater increase in the earnings component of inequality as well as a stronger reduction in inequality from the transfer and tax components than Slovakia.

An important topic for future research is whether the Czech and Slovak governments were efficient in their targeting of transfers and setting the tax rates as a means of countering the effects of the market on income inequality. Hence, the disincentive effects of increases in the share of income paid in taxes and received as transfers must be weighed against their benefits. Dampening growth in inequality by putting more weight on increasing the progressivity and share of taxes versus stricter targeting of transfers will have different long run consequences for the growth and the welfare of their citizens.

One also needs to consider the extent to which an extremely egalitarian distribution of income is desirable per se. In concluding, we would like to point out that the process of transition from socialism to capitalism was accompanied by a deep recession. Since these governments required popular support to succeed, it is understandable they would have been concerned about a major widening in income inequality as reflected in their social policies. We also expect that in the future, as the returns from asset distribution are reaped, we will see more inequality in these countries.

\section{Endnotes}

1. We would like to thank all those who improved this paper with their comments and suggestions: Simon Commander, Simon Johnson, Jan Svejnar, Jonathan Wadsworth and Anthony Yezer. The paper benefited from presentations at the following: Meeting of the 
European Society for Population Economics in Uppsala, Sweden in June 1996; the seminar on 'Issues in International Comparisons of Inequality' at Abo Akedemi University, Finland in August 1996; the joint AEA-ACES session 'Distributional Effects of Economic Transition' in New Orleans, January 1997; the conference on 'Inequality and Poverty in Transition Economies' at the EBRD, May 1997; and the conference on 'Labour Markets in Transitional Economies', William Davidson Institute, University of Michigan Business School, October 1997. We would also like to thank the many individuals who provided assistance to us while we were conducting this research: Helena Suknikova of the Slovak Statistical Office, Ing. Z. Kucharova and Ph. Dr. J. Kalmus of the Czech Statistical Office, Tim Smeeding and Cheri Minton of the Luxembourg Income Study, and William Chan, Klas de Vos, Mike Fratantoni, Sajid Qreshi, Patricia Roazklis, and Vit Sorm (from various institutions). Thanks also are extended to Jiri Vecernik, and others in the Czech Republic and in Slovakia for answering questions, beyond the call of duty. The views are those of the authors and do not reflect the policies of the Bureau of Labour Statistics or other affiliations.

2. The Visegrad countries are Hungary, Poland, the Czech Republic and Slovakia.

3. The WDR does not specify the data sources used for the Gini calculations, nor the method used to produce the Ginis. Using different data sources can affect the Gini results, as can different definitions of income for the same country and for the same time period (see Deininger and Squire, 1996 for examples). The level of data aggregation can also affect the size of the Gini coefficients. Lerman and Yitzhaki (1989) warn that '... comparing Ginis calculated with data grouped at different levels of aggregation will yield biased results' (page 46).

4. The WDR inequality results for the Czech Republic should be questioned since the Gini coefficients are based on data from two different surveys with different purposes, questions and sample designs (communication with S. Chen of the World Bank, 2/27/98; Flemming and Micklewright , 1997).

5. This finding is not specific to 1993. Vecernik (1995) using Microcensus data and Garner (1998) using Family Budget Survey data also found that income inequality in 1992 had hardly changed as compared to 1989 in the Czech and Slovak Republics.

6. By 1994 both economies were growing; during 1994-97 the Slovak GDP grew at a faster rate than the Czech GDP.

7. This section draws on Kotrba and Svejnar (1994) and Kotrba (1995).

8. According to the 1993 Statistical Yearbook for the Czech Republic, total fixed assets in current prices for 1991 were 2,795 billion crowns (Table 10-7, p.193). An exchange rate of 29 crowns per US $\$$ was used.

9. Slovak total fixed assets in current prices were 1,179 billion crowns in 1992 (Table III.52, p.168 of the 1994 Statistical Yearbook for Slovakia). Due to gaps in data series in the two statistical yearbooks we are unable to produce the same calculation for fixed assets in the two republics for the same year.

10. For more detailed discussions of the income policies, see Flek (1996) and Ham, Svejnar and Terrell (1995).

11. The eligibility criteria were fairly encompassing: anyone who was registered as unemployed by the district Labour Office and who had worked a minimum of twelve months within the previous three years was eligible for unemployment benefits. In addition, full-time students who graduated from high school or university were also eligible to receive unemployment benefits. People were entitled to six months of benefits.

The replacement rate during the first three months of the entitlement period was 60 per cent of the previous net-of-tax average wage. The rate fell to 50 per cent for the next three months. Self-employed persons who quit their activity could receive benefits as 
long as they had paid sickness and pension insurance contributions. The maximum level of benefits was set at 1.5 times the minimum wage for all unemployed persons not receiving training and 1.8 times the minimum wage for those receiving training. The benefit for graduating students was equal to 60 per cent of the minimum wage for the first half of the entitlement period and 50 per cent of the minimum wage in the second half.

12. For those retiring one to two years before the legal retirement age, the pension was reduced by 1.0 per cent of the base for each 90 days left to the official retirement age, after which the pension was calculated on the normal basis. For those who elected to retire between two and three years prior to the official retirement age, their pension was lowered by 0.6 per cent of the base for the remainder of their retirement years.

13. In this section, only new parts of the social safety net are discussed in order to limit the scope of the paper. This section draws heavily from Terrell and Münich (1995) and Terrell et al., (1995).

14. By 1994 (1996) most of social assistance was means tested in Slovakia (Czech Republic).

15. Since the minimum living standard and unemployment benefits did not exist in 1989 , we could not carry out this comparison for 1989 .

16. This ratio is 0.877 for the Czech Republic and 0.886 for Slovakia. It is based on all taxes: income, property taxes, mandatory payroll taxes, etc. Obviously any adjustment will have its problems since income tax is based on household income, but we are relying on the law of averages.

17. In practice, the person would receive his/her unemployment benefit (from the district labour office) and then receive the difference between the minimum living standard and the unemployment benefit as a social assistance benefit (from the social assistance office).

18. In the 1993 (1989) data, the average number of months that households maintained diaries was 11.2 (11.7) in the Czech Republic and 11.0 (11.6) in Slovakia. For our analysis, we annualized the incomes when less than 12 months of data were reported.

19. See Garner and Fratantoni (1997) for details on the creation of these weights. In 1988, the social groups (i.e. the workers, employees, heads working as agricultural co-operative farmers, and pensioner-headed households without other economically active members) in the 1989 FBS represented about 95 per cent of all households in the Czech Republic and 94 per cent in Slovakia. (Beginning in 1992, the agriculture social group for the FBS was redefined as households headed by persons working in agriculture including the selfemployed). By 1992, with the addition of households headed by self-employed persons to the sampled social groups, the FBS households represented 94 per cent of all households in the Czech Republic and 88 per cent in Slovakia. The missing groups in both years were: i) pensioner-headed households with economically active members, which in 1992 represented about 4.2 (8.2) per cent of all households in the Czech (Slovak) Republic; ii) households headed by non-working persons not receiving a pension or wage, which in 1992 represented about 1.8 (3.8) per cent of all households in the Czech (Slovak) Republic; in 1989 these households represented about $0.4(0.3)$ per cent of Czech (Slovak) households. The self-employed were not sampled for the 1989 FBS. These households accounted for about 0.207 per cent of Czech households in 1988 and 0.16 per cent of Slovak households (see Garner and Terrell (1997) and authors' own calculations).

20. In 1989, 5 (6) households were dropped from the original sample in the Czech (Slovak) Republics and, in 1993, two households were dropped for each republic because adequate information was not available to create household weights. 
21. Differences in household composition can affect the size of the inequality estimates. See Coulter et al. (1992) and Buhmann et al. (1992) for discussions of the sensitivity of inequality measures to equivalence scales.

22. We would have liked to analyse agricultural self-employment income as part of earnings from self-employment but this was not possible given the construction of the dataset. In 1993, the statistical offices grouped self-employment income from agriculture with other earned income. In 1992, when farm and non-farm self-employment income were separated, the per capita shares of total after-tax income of self-employed farmers was very small-0.1 per cent in the Czech Republic and 0.4 per cent in Slovakia (Garner, 1998).

23. Self-employment income is reported net of tax.

24. We would have liked to isolate 'returns on stocks and bonds', but this income was not recorded separately in the dataset.

25. In-kind consumption is valued by the statistical offices at current prices in the area in which the household lives. It includes food and beverages, rent-in-kind, and other products and services. These goods and services could have been received as gifts, as payment-in-kind, or the household could have produced them. Home production is primarily limited to agricultural production for home consumption.

26. We would have liked to group 'other family benefits' with 'child allowances' but the construction of the dataset did not allow this in 1989.

27. See Garner (1998) for a similar application of this method using per capita Ginis with 1989 and 1992 expenditure and income data from the Czech and Slovak Republics.

28. $R_{i}$ is the correlation between component $i$ and the cumulative distribution of after-tax income $y_{i}$.

29. Jackknife estimators of the standard errors were calculated for the Gini using the method proposed by Yitzhaki (1991). For the difference in the Gini coefficients between two years, the test statistic is:

$$
t=\left(G_{y 93}-G_{y 89}\right) / \sqrt{{s e_{93}^{2}+s e_{89}^{2}}^{2}}
$$

where $s e$ is the jackknife standard error of the Gini.

30. It is interesting to note that the rise in the Gini coefficient based on per capita after-tax income over this time period is smaller, but relatively larger for Slovakia: 0.009 points in Slovakia (from 0.176 to 0.185 ) and only 0.004 points in the Czech Republic (from 0.183 to 0.187 ). Hence, by this measure, the point difference between the two countries' Gini coefficients is closing.

31. Milanovic (1997) reports a 0.236 point increase in the Gini (using per capita disposable income) for Russia from 1989 (when it was 0.219) to 1994 (when it was 0.455). Similarly, the Gini for Latvia rose from 0.226 in 1989 to 0.326 in 1996.

32. The finding that inequality growth in the first years of transition in the CEE countries was less than inequality growth in the FSU countries arose at the EBRD Conference on Inequality and Poverty in Transition Economies, May, 1997 (e.g. Commander et al., 1997; Förster and T6th, 1997; and Milanovic, 1997) and is also supported by work of others (e.g. Flemming and Micklewright, 1997; Kattuman and Redmond, 1997; Yitzhaki, 1997). 


\section{References}

Atkinson A. B. and J. Micklewright (1992), Economic Transformation in Eastern Europe and the Distribution of Income, Cambridge: Cambridge University Press.

Bednarik, R. (1998), Research Institute of Labour, Social Affairs and Family, Bratislava, Slovakia, personal communication by e-mail, March 26.

Buhmann B., L. Rainwater, G. Schmaus, and T. M. Smeeding (1992), 'Equivalence Scales, Well-Being, Inequality, and Poverty: Sensitivity Estimates Across Ten Countries Using the Luxembourg Income Study (LIS) Database', Review of Income and Wealth, 34(2), pp.11542.

Commander S., A. Tolstopiatenko and R. Yemtsov (1997), 'Channels of Redistribution: Inequality and Poverty in the Russian Transition', World Bank, unpublished paper.

Coulter, F. A. E., F. A. Cowell and S. P. Jenkins (1992), 'Differences in Needs and Assessment of Income Distribution', Bulletin of Economic Research, 44(2), pp.77-124.

Deininger K. and L. Squire (1996), 'A New Data Set Measuring Income Inequality', The World Bank Economic Review, 10(3), September, pp.565-91.

Dyba K. and J. Svejnar (1995), 'A Comparative View of Economic Developments in the Czech Republic', In: Svejnar, J., ed., The Czech Republic and Economic Transition in Eastern Europe, New York: Academic Press.

Flek V. (1996), 'Macroeconomic Targets and Microeconomic Effects of Wage Policies in Transition Economies', Working Paper No.32, Czech National Bank Institute of Economics.

Flemming, J. and J. Micklewright (1997), 'Income Distribution, Economic Systems and Transition', unpublished paper, UNICEF International Child Development Centre, Florence, Italy, incomplete draft of a chapter for the Handbook of Income Distribution, edited by Atkinson, A. B. and F. Bourguignon, to be published by North-Holland.

Förster M. and I. G. Tóth (1997), 'Poverty and Inequalities: Hungary and the Visegrad Countries Compared', paper presented at conference on 'Inequality and Poverty in Transition Economies,' held at EBRD May 1997, London.

Garner T. I. (1998), 'Changing Welfare in a Changing World? Income and Expenditure Inequalities in the Czech and Slovak Republics', In: Jenkins, S. P., A. Kapteyn and B. van Praag, eds., The Distribution of Welfare and Household Production: International Perspectives, Cambridge: Cambridge University Press.

Garner T. I. and M. Fratantoni (1997), 'Creating Weights for the Czech and Slovak Family Budget Surveys using Microcensus Data', unpublished data, Bureau of Labor Statistics, Washington, D.C.

Garner T. I., M. Lubyova and K. Terrell (1995), 'Changes in Expenditures and Income Inequality: An Examination of the Micro-Data (1989 vs. 1992)', Ch.15, In: Svejnar, J., ed., The Czech Republic and Economic Transition in Eastern Europe, San Diego: Academic Press.

Garner T. I. and K. Terrell (1997), 'Changes in Income Distribution in Transition Economies: Market vs. Policy in the Czech Republic and Slovakia', Davidson Institute Working Paper No.119, University of Michigan Business School.

Ham J., J. Svejnar and K. Terrell (1995), 'Czech Republic and Slovakia', In: Commander, S. and F. Coricelli, eds., Unemployment, Restructuring, and the Labor Market in Eastern Europe and Russia, Washington, D.C.: The World Bank.

Heady C. and S. Smith (1995), 'Tax and Benefit Reform in the Czech and Slovak Republics', Centre for Economic Policy Research Discussion Paper Series, No.1 151, March.

Kattuman P. and G. Redmond (1997), 'Income Inequality in Hungary 1987-1993', unpublished manuscript drafted October, University of Durham, UK.

Kotrba J. and J. Svejnar (1994), 'Rapid and Multifaceted Privatization: the Experience of the Czech and Slovak Republics', MOCT-MOST, 4(2), pp.147-85. 
Kotrba J. (1995), 'Privatization Process in the Czech Republic: Players and Winners', Ch. 8 In: Svejnar, J., ed., The Czech Republic and Economic Transition in Eastern Europe, New York: Academic Press.

Lerman R. I. and S. Yitzhaki (1985), 'Income Inequality Effects by Income Source: A New Approach and Applications to the US', Review of Economics and Statistics, 67(1), pp.1516.

Lerman R. I. and S. Yitzhaki (1989), 'Improving the Accuracy of Estimates of Gini Coefficients', Journal of Econometrics, 42(1), pp.43-7.

Lerman R. I. and S. Yitzhaki (1994), 'The Effect of Marginal Changes in Income Sources on US Income Inequality', Public Finance Quarterly, 22(4), pp.403-17.

Milanovic B. (1997), 'Explaining the Growth in Inequality during the Transition', unpublished manuscript, April 30, Washington D.C.: The World Bank.

OECD (1982), The OECD List of Social Indicators. Paris: OECD.

Terrell K. and D. Münich (1995), 'A Review of the Evidence on the Effectiveness of the Passive and Active Labor Market Policies in the Czech Republic', In: OECD Symposium Series, Labour Market Policies in the Central and East European Countries.

Terrell K., M. Lubyova and M. Strapec (1995), 'A Review of the Evidence on the Effectiveness of the Passive and Active Labor Market Policies in the Slovak Republic', In: OECD Symposium Series, Labour Market Policies in the Central and East European Countries.

Večerník J. (1995), 'Incomes in Central Europe: Distributions, Patterns, and Perceptions', paper presented at the LIS Summer Workshop for Russian and Eastern European Studies, Walfgerdange, Luxembourg.

Vecerník J. (1996), Markets and People: The Czech Reform Experience in a Comparative Perspective, Aldershot, England: Avebury, Ashgate Publishing, Inc.

The World Bank (1996), World Development Report 1996, Washington, D.C.: The World Bank.

Yitzhaki S. (1991), 'Calculating Jackknife Variance Estimators for Parameters of the Gini Method,' Journal of Business and Economics Statistics, 9, pp.235-9.

Yitzhaki S. (1997), 'The Effect of Marginal Changes in Prices on Income Inequality in Romania', Research on Economic Inequality, 7, pp.241-58. 